\title{
The role of gender diversity on firm performance: a regression quantile approach
}

\section{Nihat Solakoglu}

To cite this article: M. Nihat Solakoglu (2013) The role of gender diversity on firm performance: a regression quantile approach, Applied Economics Letters, 20:17, 1562-1566, DOI:

10.1080/13504851.2013.829184

To link to this article: https://doi.org/10.1080/13504851.2013.829184

Published online: 28 Aug 2013.

Submit your article to this journal

Џll Article views: 612

Citing articles: 4 View citing articles $ک \pi$ 


\title{
The role of gender diversity on firm performance: a regression quantile approach
}

\author{
M. Nihat Solakoglu \\ Department of Banking \& Finance, Bilkent University, Bilkent, Ankara, Turkey \\ E-mail:nsolakoglu@bilkent.edu.tr
}

The relationship between gender diversity and firm performance has been investigated using a regression quantile approach for the largest Turkish firms. Overall, results show that gender diversity has a different effect on firm performance over the different points of the conditional distribution. Moreover, the type of industry seems to be important for the sign and significance of the impact of gender diversity on performance.

Keywords: gender diversity; firm performance; regression quantile estimation

JEL Classification: G34; G30; J16; C10

\section{Introduction}

The role of gender diversity on firm performance has been investigated several times in the past. Gender diversity has been measured using mostly observable diversity, such as women at top management positions, rather than nonobservable diversity, such as education and knowledge (Erhardt et al., 2003). It has been expected that gender diversity influences firm performance positively due to (i) higher creativity and innovation under a heterogeneous board, (ii) a positive link between diversity and the corporate image, (iii) the larger sample of qualified candidates for top positions and (iv) the broader view of the business environment to reach better decisions. However, because of diversity if decision-making takes more time, firm performance may decrease in sectors that require a quick response to market shocks (Carter et al., 2003; Smith et al., 2005).

The related empirical literature provides mixed evidence. For example, Farrell and Hersch (2005), Wolfers (2006) and Campbell and Minguez-Vera (2007) find no relationship between gender diversity and firm value. On the other hand, Smith et al. (2005), Carter et al. (2003) and Erhardt et al. (2003) provide evidence that gender diversity is positively associated with firm performance. This study also adds to the existing empirical literature by investigating the role of gender diversity on firm performance in the largest listed firms in Turkey using the regression quantiles (RQ) approach of Koenker and Bassett (1978) to evaluate the relationship at every point of the conditional distribution.

The remainder of the article is organized as follows. In Section II, we discuss data sources and the estimation approach. Section III presents our findings. Section IV concludes.

\section{Data and Methodology}

The data used in this study's analysis were obtained from the Borsa Istanbul's website for the years 2005-2006 from individual firm-level and summary reports for the firms listed in the National-100 index. ${ }^{1}$ For financial information, annual financial tables are utilized for the information.

\footnotetext{
${ }^{1}$ The web address for Borsa Istanbul is www.borsaistanbul.com. The data at this website are only made available up to 2008. Data for the years 2007 and 2008 are not used in this study due to the global financial crisis during that time.
} 
Table 1. Descriptive statistics for 2006

\begin{tabular}{llllllll}
\hline & & & & \multicolumn{7}{c}{$\begin{array}{l}\text { Percentage of } \\
\text { fumber of female on board of } \\
\end{array}$} & Firm size & Firm age & Board size & $\begin{array}{l}\text { Percentage of female } \\
\text { directors }\end{array}$ & $\begin{array}{l}\text { Export } \\
\text { dependence (\%) }\end{array}$ \\
\hline All sample & 2232 & 35.21 & 7.72 & 0.71 & 9.05 & 4.88 & 16.27 \\
Manufacturing & 1748 & 37.33 & 7.38 & 0.64 & 8.21 & 0.00 & 25.81 \\
Financial & 2340 & 36.31 & 8.42 & 0.62 & 7.00 & 7.69 & 0.00 \\
\hline
\end{tabular}

Notes: Firm size: average number of employees over the 2002-2006 period. Firm age is measured as the number of years since the establishment year. Export dependence is the average share of exports in sales for the 2002-2006 period.

Table 1 reports the descriptive statistics for 2006 since it is the year we use for estimation. On average, $9 \%$ of the board of directors of companies in the National-100 index are female, which is comparable to the $9.2 \%$ reported for the United States (Carter et al., 2003) and the 12.26\% reported for 1000 Fortune firms (Farrell and Hersch, 2005), but larger than the $3.2 \%$ reported for Spain (Campbell and Minguez-Vera, 2007). The percentage of women in top management positions, however, seems to lag behind board representation. In addition, most female top manager positions appear to be in the financial sector firms. Surprisingly, however, the number of board positions and the proportion of board positions held by women are lower in financial sector firms than in manufacturing firms.

The analysis is performed using the following model:

$$
\mathrm{PERF}_{i, t}=\alpha+\beta \mathrm{DIV}_{i,(t-1)}+\gamma \mathbf{C T R L}_{i}+\mathrm{u}_{i, t}
$$

In this model, DIV represents gender diversity and is measured by (i) a dummy variable taking the value of 1 if the top management position changes from a male to a female manager in the previous year, ${ }^{2}$ (ii) a board additions indicator that accounts for a female director addition to or removal from the board and (iii) the change in the proportion of female directors on the board, with a positive change indicating an improvement in gender diversity. $\mathrm{PERF}_{i}$ is the change in performance and is represented by two accounting and one market-based measures. The measures we consider are return on assets (ROA), return on invested capital (ROI) and average monthly return in a year divided by the monthly standard deviation of returns in the same year. This last measure normalizes the average monthly return by the total risk of the return, as measured by the standard deviation of the monthly returns in a year. ${ }^{3}$ In other words, we argue that market performance is the amount of market return per unit of risk taken. If there are differences in the risk-taking behaviour of female and male managers/directors (Jianakoplos and Bernasek, 1998), this normalization should become important. In addition, the analysis also uses as control variables (CTRL) the age of the firm, the size of the firm as measured by the number of employees and the board size (see Smith et al., 2005).

This study allows 1 year for the effect of gender diversity to have an impact on firm performance for two reasons. As discussed in Erhardt et al. (2003), the impact of a female manager or a board member on firm performance is not instantaneous and requires at least a year to make a difference. Moreover, it is not clear whether women bring a new perspective that adds value to a firm's performance or if rather higher-performing firms focus more on gender diversity. By using the lagged diversity measure, this analysis tries to capture the effect of gender diversity on future performance. In other words, the lagged gender diversity measure is used as an instrumental variable in the analysis.

Instead of relying solely on mean regression models, this study applies the RQ approach developed by Koenker and Bassett (1978) to obtain a more complete picture of the relationship between the independent variables and the dependent variable at different points of the conditional distribution. To introduce this estimation technique briefly, let $y_{i}(i=1, \ldots, n)$ denote the response variable and $\mathbf{x}_{i}{ }_{i}(i=1, \ldots, n)$ denote a sequence of row vectors. Let $u_{i}=y_{i}-\mathbf{x}_{i} \beta(\theta)$ have a distribution function $F$, where ${ }_{i} \beta(\theta)$ is an unknown vector of parameters whose estimation for different values of the $\theta$ th quantile, $0<\theta<1$, is the aim of the study. The $\theta$ th RQ is a vector $\hat{\boldsymbol{\beta}}(\theta)$ that solves the following with linear programming methods:

$$
\min _{\beta \in \mathrm{R}^{\mathrm{k}}}\left[\sum_{i \in\left\{i: y_{i} \geq \mathrm{x}^{\prime}{ }_{i} \beta\right\}} \theta\left|y_{i}-\mathrm{x}_{i}^{\prime} \beta\right|+\sum_{i \in\left\{i: y_{i}<\mathrm{x}^{\prime}{ }_{i} \beta\right\}}(1-\theta)\left|y_{i}-\mathrm{x}_{i}^{\prime} \beta\right|\right]
$$

It is well known that the estimation results of mean regression models are not robust with respect to outliers and non-Gaussian distributions. The RQ estimation technique, on the other hand, is a robust alternative to mean

\footnotetext{
${ }^{2}$ The replacement of a female manager with another female manager is not considered as an improvement in gender diversity.

${ }^{3}$ In a way, this measure is the inverse of the coefficient of variation.
} 
regression models with respect to these issues (Koenker and Bassett, 1978; Keonker and Hallock, 2001).

\section{Results}

A quick glance at the empirical cumulative distributions for the firm performance measures shows that they are not normally distributed. Furthermore, the normality of these measures is rejected by the Jargue-Bera normality test. In particular, for accounting measures, distributions are skewed with thicker tails. ${ }^{4}$ Figure 1 presents the plot of coefficient estimates on the gender diversity measure and the $10 \%$ confidence band at different quantiles. The leastsquares estimates are presented with a horizontal line in the same figures. While the first column of the figures uses ROA as the measure of performance, the second and third columns use ROI and market-based measures, respectively.

When gender diversity is measured by the CEO dummy, results show that accounting measures of performance decline significantly at the right tail of the conditional distribution. For market-based measure, however, the decline in performance appears to be at the left tail. For gender diversity measures related to the existence of women on the board, results indicate a worsening at the left tail of the distribution for market-based measures, and an improvement around the middle of the distribution for accounting-based measures. Collectively, the results provide some evidence that the existence of women on the board improves the accounting performance for average or above-average performing firms. On the other hand, firms with a high coefficient of variation are negatively impacted by gender diversity. If women are more riskaverse than men in financial decision-making (Jianakoplos and Bernasek, 1998), then gender diversity may lead to lower performance. It should also be noted that none of the least-squares estimates are statistically significant in Fig. 1.

As discussed in the literature, industry characteristics can be important for the performance and representation of women in top management positions or on boards of directors and can be different for different types of industries (Harrigan, 1981; Farrell and Hersch, 2005). Since
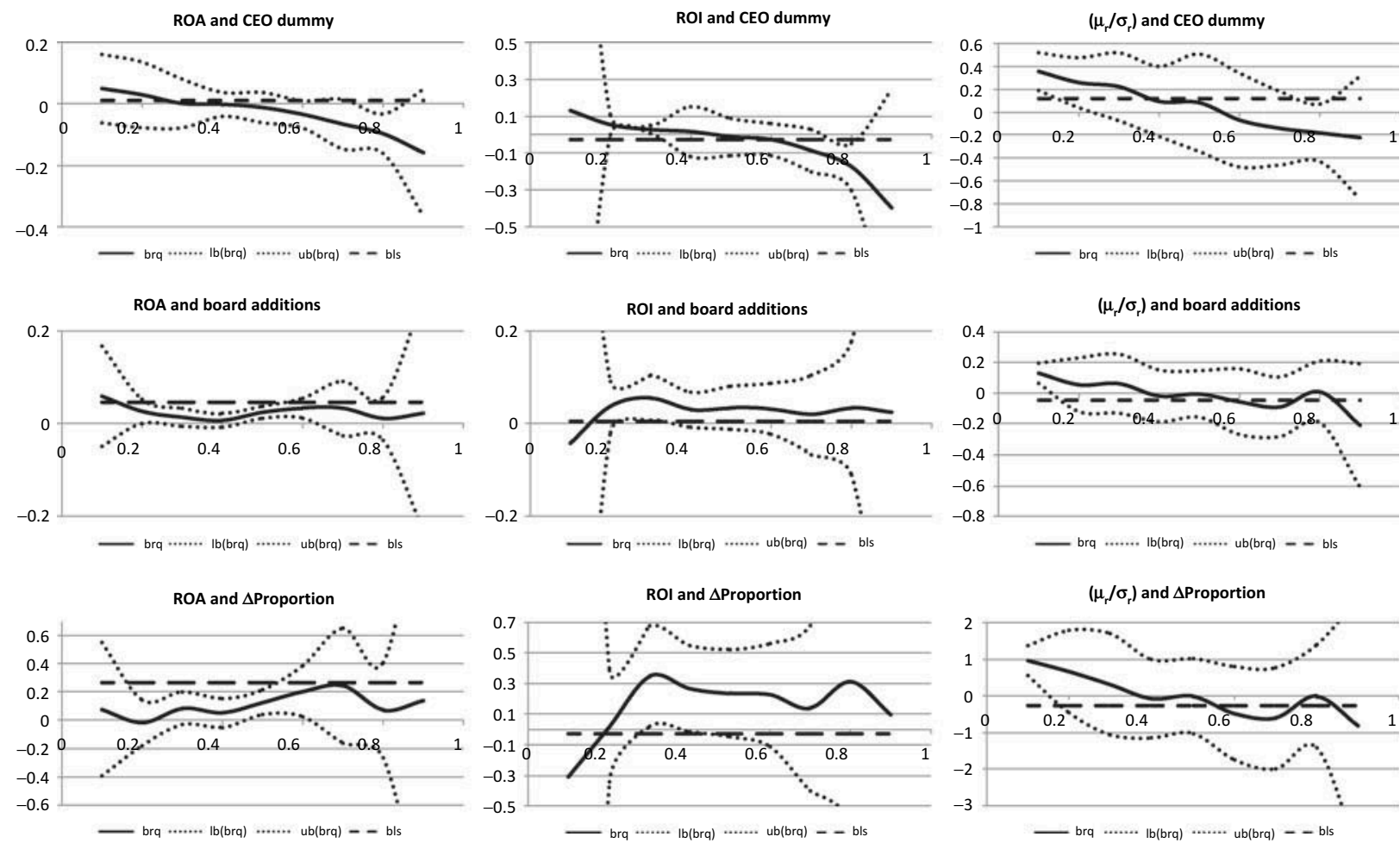

Fig. 1. Estimation results

Notes: In the figure, brq denotes regression quantile estimates; $\mathrm{lb}$ and ub represent lower and upper bounds for the $90 \%$ confidence interval for regression quantile estimates. Least-squares estimates are represented by the dashed line and denoted by bls.

${ }^{4}$ The skewness and kurtosis coefficients for ROA, ROI and the market-based measure (R_V) are $(1.57,10.75),(-5.12,38.71)$ and $(0.60$, 3.67), respectively. 
Table 2. Industry and the role of gender diversity

\begin{tabular}{|c|c|c|c|c|c|c|c|c|c|}
\hline \multirow[b]{2}{*}{ Quantiles } & \multicolumn{3}{|l|}{ ROA } & \multicolumn{3}{|l|}{ ROI } & \multicolumn{3}{|l|}{$\left(\mu_{\mathrm{r}} / \sigma_{\mathrm{r}}\right)$} \\
\hline & $\begin{array}{l}\text { CEO } \\
\text { additions }\end{array}$ & $\begin{array}{l}\text { Board } \\
\text { additions }\end{array}$ & $\begin{array}{l}\text { Change in } \\
\text { board }\end{array}$ & $\begin{array}{l}\mathrm{CEO} \\
\text { additions }\end{array}$ & $\begin{array}{l}\text { Board } \\
\text { additions }\end{array}$ & $\begin{array}{l}\text { Change in } \\
\text { board }\end{array}$ & $\begin{array}{l}\mathrm{CEO} \\
\text { additions }\end{array}$ & $\begin{array}{l}\text { Board } \\
\text { additions }\end{array}$ & $\begin{array}{l}\text { Change in } \\
\text { board }\end{array}$ \\
\hline \multicolumn{10}{|c|}{ Manufacturing firms } \\
\hline $10 \%$ & $\begin{array}{c}0.0230 \\
(0.077)\end{array}$ & $\begin{array}{c}-0.0092 \\
(0.0462)\end{array}$ & $\begin{array}{c}-0.0566 \\
(0.291)\end{array}$ & $\begin{array}{c}-0.4259 \\
(0.4207)\end{array}$ & $\begin{array}{c}-0.2095 \\
(0.2853)\end{array}$ & $\begin{array}{c}-1.4965 \\
(1.8996)\end{array}$ & $\begin{array}{c}-0.0652 \\
(0.052)\end{array}$ & $\begin{array}{l}0.2064 * * * \\
(0.0391)\end{array}$ & $\begin{array}{l}1.2969^{* * *} \\
(0.2496)\end{array}$ \\
\hline $25 \%$ & $\begin{array}{l}0.0443 * * * \\
(0.0107)\end{array}$ & $\begin{array}{c}0.0274^{*} \\
(0.0138)\end{array}$ & $\begin{array}{c}0.1660^{*} \\
(0.0882)\end{array}$ & $\begin{array}{c}0.0352 \\
(0.0427)\end{array}$ & $\begin{array}{c}0.0684 \\
(0.0458)\end{array}$ & $\begin{array}{c}0.4134 \\
(0.2909)\end{array}$ & $\begin{array}{l}-0.0075 \\
(0.0775)\end{array}$ & $\begin{array}{l}0.1236 \\
(0.1228)\end{array}$ & $\begin{array}{l}0.7546 \\
(0.6055)\end{array}$ \\
\hline $50 \%$ & $\begin{array}{l}0.0873 * * * \\
(0.0195)\end{array}$ & $\begin{array}{c}0.0552^{*} \\
(0.0293)\end{array}$ & $\begin{array}{l}0.4517 * * * \\
(0.1423)\end{array}$ & $\begin{array}{l}0.1051 * * * \\
(0.0282)\end{array}$ & $\begin{array}{c}0.1022 \\
(0.0678)\end{array}$ & $\begin{array}{l}0.7745^{*} \\
(0.413)\end{array}$ & $\begin{array}{l}0.2076^{* *} \\
(0.0868)\end{array}$ & $\begin{array}{c}-0.0084 \\
(0.1465)\end{array}$ & $\begin{array}{c}-0.0583 \\
(0.9749)\end{array}$ \\
\hline $75 \%$ & $\begin{array}{l}0.1225^{* * *} \\
(0.0228)\end{array}$ & $\begin{array}{c}0.0309 \\
(0.045)\end{array}$ & $\begin{array}{c}0.1587 \\
(0.2676)\end{array}$ & $\begin{array}{l}0.1519 * * * \\
(0.0491)\end{array}$ & $\begin{array}{c}0.0594 \\
(0.0721)\end{array}$ & $\begin{array}{c}0.3957 \\
(0.4371)\end{array}$ & $\begin{array}{l}0.4033^{* * *} \\
(0.0705)\end{array}$ & $\begin{array}{c}0.0741 \\
(0.0963)\end{array}$ & $\begin{array}{c}-0.8869 \\
(1.3629)\end{array}$ \\
\hline $90 \%$ & $\begin{array}{l}0.1899 * * \\
(0.0439)\end{array}$ & $\begin{array}{l}0.0783 * * * \\
(0.01)\end{array}$ & $\begin{array}{c}0.5436^{*} \\
(0.2943)\end{array}$ & $\begin{array}{l}0.2495 * * * \\
(0.0567)\end{array}$ & $\begin{array}{l}0.0839^{* *} \\
(0.0366)\end{array}$ & $\begin{array}{r}0.1079 \\
(0.589)\end{array}$ & $\begin{array}{l}0.6141^{* * * *} \\
(0.1113)\end{array}$ & $\begin{array}{c}-0.1776 \\
(0.243)\end{array}$ & $\begin{array}{c}-1.5215 \\
(1.611)\end{array}$ \\
\hline \multicolumn{10}{|c|}{ Nonmanufacturing Firms } \\
\hline $10 \%$ & $\begin{array}{c}0.0591^{*} \\
(0.0351)\end{array}$ & $\begin{array}{l}0.0730 * * * \\
(0.003)\end{array}$ & $\begin{array}{c}0.0741 \\
(0.3027)\end{array}$ & $\begin{array}{c}0.1074 \\
(0.9309)\end{array}$ & $\begin{array}{c}-0.0299 \\
(0.9676)\end{array}$ & $\begin{array}{c}-0.2376 \\
(6.9002)\end{array}$ & $\begin{array}{l}0.3455^{* * *} \\
(0.1075)\end{array}$ & $\begin{array}{c}0.0118 \\
(0.0576)\end{array}$ & $\begin{array}{c}0.0723 \\
(0.3613)\end{array}$ \\
\hline $25 \%$ & $\begin{array}{c}0.0299 \\
(0.0243)\end{array}$ & $\begin{array}{c}0.0299 \\
(0.0263)\end{array}$ & $\begin{array}{c}-0.0575 \\
(0.1616)\end{array}$ & $\begin{array}{c}0.0395 \\
(0.0448)\end{array}$ & $\begin{array}{l}0.0444 \\
(0.05)\end{array}$ & $\begin{array}{c}0.3704 \\
(0.2343)\end{array}$ & $\begin{array}{l}0.3041 * * * \\
(0.1128)\end{array}$ & $\begin{array}{c}-0.0121 \\
(0.1114)\end{array}$ & $\begin{array}{c}-0.0679 \\
(0.7729)\end{array}$ \\
\hline $50 \%$ & $\begin{array}{c}-0.0045 \\
(0.0106)\end{array}$ & $\begin{array}{c}0.0133 \\
(0.0097)\end{array}$ & $\begin{array}{c}0.0605 \\
(0.0792)\end{array}$ & $\begin{array}{c}0.0174 \\
(0.0234)\end{array}$ & $\begin{array}{c}0.0252 \\
(0.0332)\end{array}$ & $\begin{array}{c}0.1916 \\
(0.2588)\end{array}$ & $\begin{array}{c}0.0403 \\
(0.0848)\end{array}$ & $\begin{array}{c}-0.1421 \\
(0.1007)\end{array}$ & $\begin{array}{c}-0.1655 \\
(0.7144)\end{array}$ \\
\hline $75 \%$ & $\begin{array}{c}-0.0197 \\
(0.0206)\end{array}$ & $\begin{array}{c}0.0219 \\
(0.0255)\end{array}$ & $\begin{array}{c}0.0732 \\
(0.1991)\end{array}$ & $\begin{array}{c}-0.1137^{* *} \\
(0.0556)\end{array}$ & $\begin{array}{l}0.0771^{* * * *} \\
(0.0254)\end{array}$ & $\begin{array}{c}0.4427 \\
(0.314)\end{array}$ & $\begin{array}{c}-0.1690 \\
(0.1213)\end{array}$ & $\begin{array}{c}-0.0097 \\
(0.1983)\end{array}$ & $\begin{array}{c}-0.0935 \\
(1.2414)\end{array}$ \\
\hline $90 \%$ & $\begin{array}{l}-0.0322 \\
(0.0543)\end{array}$ & $\begin{array}{l}0.0311^{* *} \\
(0.0153)\end{array}$ & $\begin{array}{c}0.1963^{*} \\
(0.1142)\end{array}$ & $\begin{array}{c}-0.1732 \\
(0.4864)\end{array}$ & $\begin{array}{c}0.0204 \\
(0.2917)\end{array}$ & $\begin{array}{c}0.1573 \\
(1.9433)\end{array}$ & $\begin{array}{l}-0.2325 * * * \\
(0.0593)\end{array}$ & $\begin{array}{c}-0.0849 * \\
(0.0457)\end{array}$ & $\begin{array}{l}-0.8525^{* *} \\
(0.3216)\end{array}$ \\
\hline
\end{tabular}

Notes: Standard errors are presented in parentheses. Although there were no female CEOs/GMs in manufacturing in 2006, this sector had female CEOs/GMs in earlier years.

$* * *, * *, *$ represent statistical significance at $1 \%, 5 \%$ and $10 \%$, respectively.

about half of the firms in our sample are in manufacturing, Equation 1 is estimated for manufacturing and nonmanufacturing firms separately. To save space, only the coefficient estimates and the standard errors on gender diversity are reported in Table 2 .

For manufacturing firms, except at the left tail of the distribution, gender diversity as measured by the CEO dummy influences firm performance positively for all measures of performance. Other diversity measures also provide somewhat similar results. On the other hand, for nonmanufacturing firms, there does not appear to be a significant relationship between gender diversity and firm performance. Further, contrary to earlier findings, gender diversity causes the market-based performance measure to be lower at the $90 \%$ quantile for nonmanufacturing firms. It can also be argued that nonmanufacturing firms, especially the financial sector firms, require faster decision-making and hence gender diversity might be associated with lower performance, as discussed by Smith et al. (2005).

\section{Concluding Remarks}

The role of gender diversity on firm performance is examined for the largest firms in Turkey utilizing the RQ approach. Results show that gender diversity has a different effect on firm performance over the different points of the conditional distribution. For accounting-based measures, results provide some support that gender diversity improves performance for average or above-average performing firms. Furthermore, firms in the manufacturing sector that do not require quick decision-making respond positively to gender diversity, while firms in nonmanufacturing sectors either show no response or negative response.

For future research, based on the availability of data, this study should use Tobin's $Q$ as another measure and investigate the role of gender diversity with more current data. Moreover, it would be interesting to investigate the role of risk-aversion differences of women and men at different sectors on the findings of this analysis.

\section{References}

Campbell, K. and Minguez-Vera, A. (2007) The influence of gender on Spanish boards of directors: an empirical analysis, IVIE Working Paper WP-EC-2007-08, Valencian Institute of Economic Research, Valencia, pp. 1-31.

Carter, D. A., Simkins, B. J. and Simpson, W. G. (2003) Corporate governance, board diversity, and firm value, The Financial Review, 38, 33-53. 
Erhardt, N. L., Werbel, J. D. and Shrader, C. B. (2003) Board of director diversity and firm financial performance, Corporate Governance, 11, 102-11.

Farrell, K. A. and Hersch, P. L. (2005) Additions to corporate boards: the effect of gender, Journal of Corporate Finance, 11, 85-106.

Harrigan, K. R. (1981) Numbers and positions of women elected to corporate boards, Academy of Management Journal, 24, 619-25.

Jianakoplos, N. A. and Bernasek, A. (1998) Are women more risk averse?, Economic Inquiry, 36, 620-30.
Koenker, R. and Bassett Jr, G. (1978) Regression quantiles, Econometrica, 46, 33-50.

Koenker, R. and Hallock, K. F. (2001) Quantile regression, Journal of Economic Perspectives, 15, 143-56.

Smith, N., Smith, V. and Verner, M. (2005) Do women in top management affect firm performance?, A panel study of 2500 Danish firms, Discussion Paper No. 2005-03, Centre for Industrial Economics, Paris.

Wolfers, J. (2006) Diagnosing discrimination: stock returns and CEO gender. IZA Discussion Paper No. 1944, IZA, Bonn. 